\title{
Short-term effect of androgen deprivation on intraluminal pressure and contractility of the rat epididymis
}

\author{
A. Din-Udom, S. Sujarit and C. Pholpramool \\ Department of Physiology, Faculty of Science, Mahidol University, Rama VI Road, Bangkok 10400, \\ Thailand
}

\begin{abstract}
Summary. Short-term effects of bilateral castration, cyproterone acetate and unilateral efferent duct ligation on intraluminal pressures and spontaneous contractions in different regions of the epididymis were studied in the rat. Ligation of the efferent ducts for 5 days did not alter pressures or spontaneous contractions in any region of the epididymis. However, bilateral castration produced time-dependent changes in pressures and contractions in different segments. In the caput, the amplitude, but not the basal pressure or the frequency, of spontaneous contractions increased by Day 1 after operation. In the corpus, increments in the basal pressure and the amplitude of contractions occurred by Day 5 whilst the frequency of contractions was not changed. Similar effects were observed in the cauda by 3 days after castration. Changes in all regions of the epididymis were also mimicked by cyproterone acetate treatment (10 $\mathrm{mg} /$ rat per day, s.c. for 21 days). In addition, this drug increased the amplitude of contractions in the cauda. The effect of castration was abolished by testosterone propionate $(0.2 \mathrm{mg} / \mathrm{kg}$ per day, i.m. for 5 days). The results support the suggestion that an enhancement of sperm transport through the rat epididymis occurs shortly after castration. The results also suggest that, in normal rats, androgens suppress the contractility of the epididymal tubule to ensure an optimal rate of sperm transport.
\end{abstract}

\section{Introduction}

The epididymis is an androgen-dependent male sex organ (for review, see Brooks, 1981). Many secretory and absorptive processes are substantially reduced in the androgen-deprived animals (Jones \& Glover, 1973; Prasad, Rajalakshmi, Gupta \& Karkun, 1973; Wong, Au \& Ngai, 1978; Moore \& Bedford, 1979; Pholpramool \& Sornpaisarn, 1980; Pholpramool, White \& Setchell, 1982). The presence of androgens is required not only for the development of immature spermatozoa in the proximal regions of the epididymis but also for the maintenance of mature spermatozoa in the caudal regions (Bedford, 1975; Orgebin-Crist, Danzo \& Davies, 1975).

However, there have been few studies on the role of androgens in the contraction of the epididymis. Furthermore, the results so far are still contradictory: the motility of the isolated cauda epididymidis of the guinea-pig was stimulated by testosterone (Da Silva E. Souza, Gimeno \& Gimeno, 1974), but spontaneous contraction of the rat cauda epididymidis ceased after castration and was restored by testosterone replacement (Risley, 1959; Hib \& Ponzio, 1977). These results suggest that sperm transport through the epididymis would be retarded by androgen deprivation. However, evidence from the epididymal sperm reserve in the rat (Dyson \& Orgebin-Crist, 1973; Foldsey \& Bedford, 1982; Pholpramool et al., 1982) and in the hamster (Lubicz-Nawrocki, 1974) indicates that the passage of spermatozoa through the epididymis is enhanced after androgen 
withdrawal. It is assumed that inhibition of fluid absorption after androgen deprivation (Wong $e t$ al., 1978) produces an accumulation of luminal fluid and hence facilitates fluid passage into the distal regions (Foldsey \& Bedford, 1982; Pholpramool et al., 1982). Whether the increase in fluid flow in castrated animals is primarily due to an elevation in luminal hydrostatic pressure is not known. Intraluminal hydrostatic pressures and contractility of different regions of the rat epididymis can be measured by a servo-nulling pressure transducer (Pholpramool, Triphrom \& Din-Udom, 1984). In the present study, the same method has been used to determine the effect of androgen deprivation induced by bilateral castration or cyproterone acetate on intraluminal hydrostatic pressure and contractility of the rat epididymis in vivo.

\section{Materials and Methods}

Animals. Sexually mature male Fischer rats of the Mahidol University colony, weighing 200-360 g, were housed in groups of 6-8, separate from females, and with $14 \mathrm{hlight} / 24 \mathrm{~h}$ and free access to food and water.

Experiment I: effect of bilateral castration. A group of 27 rats was anaesthetized with ether (Government Pharmaceutical Organization, Bangkok, Thailand) and bilateral orchidectomy was performed through an abdominal incision. Great care was taken to avoid interruption of the blood supply to the epididymides during manipulation of both testes. The epididymides were then replaced in the scrotal sac. After the incision was closed, the animals were allowed to recover and were maintained for 1, 3 and 5 days. Another group of 23 rats, which was sham operated and maintained for the same period as the castrated animals, served as controls.

Experiment II: effect of bilateral castration and testosterone propionate. Bilateral castration was performed in a group of 5 rats as in Exp. I but the animals received subcutaneous injection ( $0.2 \mathrm{ml})$ of testosterone propionate in corn oil at a dose of $0.2 \mathrm{mg} / \mathrm{kg}$ per day for 5 days. Control animals ( 5 rats) were sham-operated and received corn oil only for 5 days.

Experiment III: effect of unilateral efferent duct ligation. Twenty-four rats were anaesthetized with ether and the testis and the epididymis on one side were exposed through an abdominal incision. The efferent ducts were carefully separated from the surrounding blood vessels and a ligature (silk thread, no. 1-0) was made close to the testis. The whole tissue was then replaced in the scrotal sac and the incision was sutured. The animals were allowed to recover and maintained for 1 , 3 or 5 days. Another group of 22 rats was sham-operated and maintained for 1, 3 or 5 days.

Experiment IV : effect of cyproterone acetate. A group of 7 rats received subcutaneous injections of cyproterone acetate dissolved in benzyl benzoate-castor oil $(50: 50, \mathrm{v} / \mathrm{v})$ at a dose of $10 \mathrm{mg} / \mathrm{rat}$ per day for 21 days. Control animals (6 rats) received only the vehicle at the same volume of injection $(0.2 \mathrm{ml})$ daily for 21 days.

Measurements of intraluminal pressure. Control and experimental animals were fasted overnight and anaesthetized with sodium 5-ethyl-5(1-methyl propyl)-2-thiobarbiturate (Inactin: Byk Gulden Konstanz, West Germany) intraperitoneally at a dose of $100 \mathrm{mg} / \mathrm{kg}$ body weight. After induction of surgical anaesthesia, the animals were prepared for micropuncture and measurements of intraluminal pressure of the epididymis as described previously (Pholpramool et al., 1984). The sites of pressure measurements were the mid-caput (site 2), the mid-corpus (site 4) and the proximal cauda (site 6).

Chemicals. Testosterone propionate was purchased from Nutritional Biochemicals Corp. (Cleveland, Ohio, U.S.A.). Cyproterone acetate was a gift from Schering A.G. (Berlin, West Germany). 
Statistical analyses. Differences between experimental and control groups were assessed by analysis of variance and Student's $t$ test at the 5\% significance level. All data are presented as mean \pm s.e.m.

\section{Results}

\section{Experiment I: effect of bilateral castration}

Caput epididymidis. Bilateral castration for 5 days had no effect on the intraluminal basal pressure of the caput, except a transient reduction $(P<0.05)$ on Day 1 after castration (Text-fig. 1a). However, a significant increase $(P<0 \cdot 01)$ in the amplitude of contraction occurred by Day 1 . The enhancement of contraction appeared to increase with time, being 2-3-fold on Day 5 compared to a 1.9-fold increase on Day 1. By contrast, the frequency of tubular contractions was not changed after castration.

Corpus epididymidis. There was a tendency for an increase in the corpus basal pressure by Day 3 but the change was significant $(P<0.05)$ only on Day 5 (Text-fig. 1b). Similarly, the amplitude of contractions was augmented $(P<0.05)$ on Day 5 when the peaks of contractions were increased almost 2-fold. The frequency of contractions was not affected by castration.

Cauda epididymidis. A significant elevation $(P<0.05)$ in the cauda basal pressure appeared by 3 days after orchidectomy (Text-fig. 1c). In contrast to the proximal regions, however, the amplitude of tubular contraction was not altered by androgen deprivation. Although there appeared to be a transient increase on Day 1, the change was not significant. As in the proximal segments of the epididymis, the frequency of contractions in the cauda was not influenced by castration.
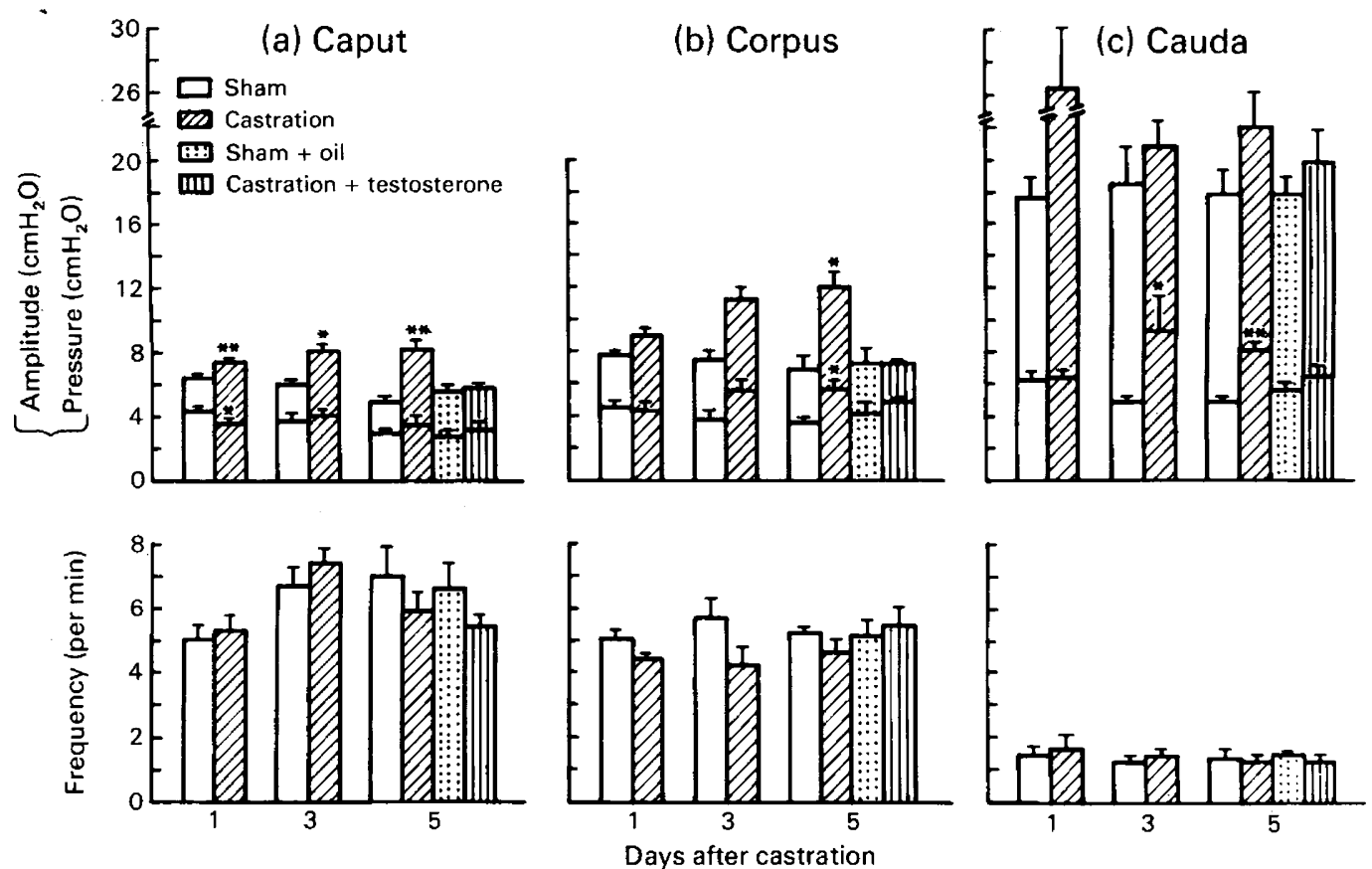

Text-fig. 1. The time course effects (on Days 1,3 and 5) of castration on the basal pressure (upper panel, lower bar graphs) and the amplitude (upper panel, upper bar graphs) and the frequency of contraction (lower panel) of (a) the caput epididymidis, (b) the corpus epididymidis and (c) the cauda epididymidis of rats. Values are mean \pm s.e.m. for 5-9 rats/group. 


\section{Experiment II: effect of bilateral castration supplemented with testosterone propionate}

The changes observed in all regions of the epididymis in the castrated rats were completely prevented when testosterone propionate was administered after castration (Text-fig. 1).

\section{Experiment III: effect of cyproterone acetate}

When cyproterone acetate was administered an increase in basal pressure occurred in the cauda, but not in the caput or the corpus, whilst an enhancement in the peak of contraction was observed in all regions (Table 1). However, the frequency of contractions was not changed.

Table 1. Effects of cyproterone acetate treatment $(10 \mathrm{mg} / \mathrm{kg}$ per day for 21 days $)$ on intraluminal pressures and contractility of different regions of the rat epididymis

\begin{tabular}{|c|c|c|c|c|}
\hline \multirow[b]{2}{*}{ Treatment } & \multirow{2}{*}{$\begin{array}{c}\text { Epididymal } \\
\text { segment } \\
\text { (no. of measurements) }\end{array}$} & \multirow{2}{*}{$\begin{array}{c}\text { Basal } \\
\text { pressure } \\
\left(\mathrm{cmH}_{2} \mathrm{O}\right)\end{array}$} & \multicolumn{2}{|c|}{ Contraction } \\
\hline & & & Amplitude $\left(\mathrm{cmH}_{2} \mathrm{O}\right)$ & Frequency (per $\min$ ) \\
\hline Control & $\begin{array}{l}\text { Caput (5) } \\
\text { Corpus (6) } \\
\text { Cauda (5) }\end{array}$ & $\begin{array}{l}2 \cdot 6 \pm 0.2 \\
3 \cdot 9 \pm 0.5 \\
4 \cdot 8 \pm 0 \cdot 3\end{array}$ & $\begin{array}{r}1.3 \pm 0.4 \\
2.6 \pm 0.4 \\
11.6 \pm 1.6\end{array}$ & $\begin{array}{l}4.5 \pm 0.5 \\
4.2 \pm 0.4 \\
1.5 \pm 0.4\end{array}$ \\
\hline Cyproterone acetate & $\begin{array}{l}\text { Caput (7) } \\
\text { Corpus (7) } \\
\text { Cauda (5) }\end{array}$ & $\begin{array}{c}2 \cdot 6 \pm 0 \cdot 4 \\
3 \cdot 6 \pm 0 \cdot 4 \\
13 \cdot 0 \pm 0 \cdot 8^{* *}\end{array}$ & $\begin{array}{l}3.3 \pm 0.5^{*} \\
5.7 \pm 0.8^{* *} \\
17.0 \pm 1.4^{*}\end{array}$ & $\begin{array}{l}5.6 \pm 0.6 \\
5.5 \pm 0.4 \\
1.8 \pm 0.2\end{array}$ \\
\hline
\end{tabular}

Values are mean \pm s.e.m.

* Significantly different from control, $P<0.05$.

** Significantly different from control, $P<0.01$.

\section{Experiment IV: effect of unilateral efferent duct ligation}

Prevention of fluid flow from the testis into the epididymis by ligation of the efferent ducts did not interfere with intraluminal pressures and contractions in any part of the rat epididymis (Table 2).

\section{Discussion}

The present study demonstrates that intraluminal pressures and/or the amplitude of contractions in all segments of the rat epididymis increased soon after (1-3 days) bilateral castration. By contrast, the frequency of tubular contractions in all regions was virtually unaffected by androgen withdrawal. The effects of castration were not simply due to surgical trauma or blockade of fluid flow from the testis because complete ligation of the efferent ducts produced no effect and the changes were abolished by testosterone replacement therapy. In addition, administration of cyproterone acetate produced effects similar to those induced by androgen deprivation. These results therefore indicate that an enhancement in basal pressure and/or amplitude of contractions of the rat epididymis was the result of androgen withdrawal. However, the lack of effect on frequency of contractions suggests that the pace-maker controlling the rhythmic spontaneous contractions of the epididymal duct is independent of androgens, at least during the initial 5-day period of androgen deprivation. The results in this study also revealed regional differences in the changes in pressures after castration.

Our data are contrary to those of Hib \& Ponzio (1977) who reported a cessation of spontaneous contractions of the distal cauda epididymidis in rats 4 days after castration. This discrepancy is probably due to regional differences in the control of tubular contraction since neural arrangements vary in different regions of the epididymis. Hib \& Ponzio (1977) measured pressures by 
Table 2. Intraluminal pressures and contractility of different regions of rat epididymis at various times after unilateral efferent duct ligation

\begin{tabular}{|c|c|c|c|c|c|}
\hline \multirow[b]{2}{*}{ Treatment } & \multirow{2}{*}{$\begin{array}{c}\text { Days } \\
\text { after } \\
\text { treatment }\end{array}$} & \multirow{2}{*}{$\begin{array}{l}\text { Epididymal } \\
\text { segment } \\
\text { (no. of } \\
\text { measurements) }\end{array}$} & \multirow{2}{*}{$\begin{array}{c}\text { Basal } \\
\text { pressure } \\
\left(\mathrm{cmH}_{2} \mathrm{O}\right)\end{array}$} & \multicolumn{2}{|c|}{ Contraction } \\
\hline & & & & $\begin{array}{l}\text { Amplitude } \\
\left(\mathrm{cmH}_{2} \mathrm{O}\right)\end{array}$ & $\begin{array}{l}\text { Frequency } \\
\text { (per min) }\end{array}$ \\
\hline \multirow[t]{3}{*}{ Sham operation } & 1 & $\begin{array}{l}\text { Caput (5) } \\
\text { Corpus (6) } \\
\text { Cauda (6) }\end{array}$ & $\begin{array}{l}3 \cdot 6 \pm 0.7 \\
3 \cdot 1 \pm 0.3 \\
5 \cdot 5 \pm 0.5\end{array}$ & $\begin{array}{r}2 \cdot 2 \pm 0 \cdot 2 \\
3 \cdot 1 \pm 0 \cdot 3 \\
12 \cdot 8 \pm 2 \cdot 2\end{array}$ & $\begin{array}{l}5.4 \pm 0.5 \\
4 \cdot 3 \pm 0.3 \\
1 \cdot 3 \pm 0.7\end{array}$ \\
\hline & 3 & $\begin{array}{l}\text { Caput (5) } \\
\text { Corpus (5) } \\
\text { Cauda (5) }\end{array}$ & $\begin{array}{l}3.2 \pm 0.1 \\
3.4 \pm 0.3 \\
5.4 \pm 0.8\end{array}$ & $\begin{array}{r}2 \cdot 0 \pm 0 \cdot 2 \\
3 \cdot 3 \pm 0 \cdot 4 \\
14 \cdot 8 \pm 0 \cdot 2\end{array}$ & $\begin{array}{l}5.4 \pm 0.5 \\
5.2 \pm 0.6 \\
1.6 \pm 0.2\end{array}$ \\
\hline & 5 & $\begin{array}{l}\text { Caput (5) } \\
\text { Corpus (5) } \\
\text { Cauda (5) }\end{array}$ & $\begin{array}{l}2.7 \pm 0.2 \\
5.1 \pm 0.5 \\
5.4 \pm 0.8\end{array}$ & $\begin{array}{r}2 \cdot 6 \pm 0.5 \\
3 \cdot 1 \pm 0.9 \\
10 \cdot 8 \pm 2.5\end{array}$ & $\begin{array}{l}6 \cdot 2 \pm 0 \cdot 5 \\
5 \cdot 2 \pm 0 \cdot 4 \\
1 \cdot 3 \pm 0 \cdot 2\end{array}$ \\
\hline \multirow[t]{3}{*}{ Unilateral efferent duct ligation } & 1 & $\begin{array}{l}\text { Caput (6) } \\
\text { Corpus (5) } \\
\text { Cauda (6) }\end{array}$ & $\begin{array}{l}3.1 \pm 0.5 \\
3.7 \pm 0.2 \\
5.4 \pm 0.6\end{array}$ & $\begin{array}{r}2 \cdot 5 \pm 0 \cdot 3 \\
3 \cdot 2 \pm 0 \cdot 1 \\
12 \cdot 8 \pm 2 \cdot 5\end{array}$ & $\begin{array}{l}6 \cdot 3 \pm 0 \cdot 4 \\
4 \cdot 4 \pm 0 \cdot 2 \\
1 \cdot 0 \pm 0\end{array}$ \\
\hline & 3 & $\begin{array}{l}\text { Caput (6) } \\
\text { Corpus (6) } \\
\text { Cauda (5) }\end{array}$ & $\begin{array}{l}3.7 \pm 0.5 \\
4 \cdot 2 \pm 0.4 \\
5.2 \pm 1.0\end{array}$ & $\begin{array}{r}2 \cdot 4 \pm 0 \cdot 3 \\
3 \cdot 4 \pm 0 \cdot 3 \\
13 \cdot 4 \pm 2 \cdot 2\end{array}$ & $\begin{array}{l}6.5 \pm 0.7 \\
4 \cdot 5 \pm 0.2 \\
1.4 \pm 0.2\end{array}$ \\
\hline & 5 & $\begin{array}{l}\text { Caput (6) } \\
\text { Corpus (7) } \\
\text { Cauda (5) }\end{array}$ & $\begin{array}{l}2.7 \pm 0.4 \\
4.7 \pm 0.4 \\
5.2 \pm 0.7\end{array}$ & $\begin{array}{r}2 \cdot 7 \pm 0.5 \\
2.8 \pm 0 \cdot 2 \\
13.2 \pm 2 \cdot 1\end{array}$ & $\begin{array}{l}6 \cdot 6 \pm 0.5 \\
4 \cdot 4 \pm 0 \cdot 3 \\
1 \cdot 2 \pm 0 \cdot 2\end{array}$ \\
\hline
\end{tabular}

Values are mean \pm s.e.m.

catheterization at the vas-distal cauda junction where the density of nerve fibres is relatively high compared to that in the proximal regions (Risley \& Skrepetos, 1964; El-Badawi \& Schenk, 1967; Hodson, 1970). There is evidence that spontaneous contractility of the proximal segments of the rat epididymis is less dependent on neural activities than the distal part and vas deferens (Hib, 1976; Pholpramool \& Triphrom, 1984). Decreases in cholinergic (Risley, 1961) and adrenergic (Norberg, Risley \& Ungerstedt, 1967) activities after long-term castration have been reported.

However, the increases in basal pressures and amplitude of tubular contractions after bilateral castration or cyproterone acetate in this study are consistent with the studies on sperm transport during androgen deprivation (Dyson \& Orgebin-Crist, 1973; Lubicz-Nawrocki, 1974; Foldsey \& Bedford, 1982; Pholpramool et al., 1982) or after oestradiol treatment (Meistrich, Hughes \& Bruce, 1975). Further, the results in this study can explain the enhancement of sperm transport in androgen-deprived animals in terms of increases in intraluminal pressure and/or amplitude of spontaneous contractions of the epididymal duct.

If it is assumed that the tonus of the contractile cells in the tubular wall remains constant, the elevation of intraluminal basal pressures could simply be due to a reduction in luminal diameter or a retention of intratubular fluid, or both. Since the time courses of changes in pressure and tubular diameter were not related, i.e. decreases in luminal diameter occurred by 3 days (the caput) or 5 days (the corpus and the cauda) after castration (unpublished observations), it is less likely that increases in pressure were primarily the consequence of decreases in luminal diameter. In view of the previous findings that fluid absorption in all segments of the rat epididymis was inhibited after castration (Wong et al., 1978), the second alternative is more likely. However, progressive regression in tubular diameter may enhance an elevation in basal pressures. Similarly, the increases in amplitude of contraction may be explained partly by changes in luminal diameter and basal pressure.

However, the possibility that contractility of the epididymal duct is increased shortly after castration cannot be excluded since increases in contractility of the vas deferens, seminal vesicles and prostate glands of androgen-deprived rats have been demonstrated (Martins \& Valle, 1939). 
The mechanism underlying this phenomenon is presently unclear. The responsiveness of rat vas deferens, seminal vesicles and prostate glands to various pharmacological agents increased after castration (Martins \& Valle, 1939) but it is not known whether this is also true for the rat epididymis.

This investigation received financial support from the Special Programme of Research, Development and Research Training in Human Reproduction, World Health Organisation and, in part, from National Research Council of Thailand. We thank Miss Suthada Homjun for secretarial assistance.

\section{References}

Bedford, J.M. (1975) Maturation, transport, and fate of spermatozoa in the epididymis. In Handbook of Physiology, Section 7: Endocrinology, Vol. 5: Male Reproductive System, pp. 303-318. Eds D. W. Hamilton \& R. O. Greep. American Physiological Soc., Washington, D.C.

Brooks, D.E. (1981) Metabolic activity in the epididymis and its regulation by androgens. Physiol. Rev. 61, 515-555.

Da Silva E. Souza, M.C., Gimeno, M.F. \& Gimeno, A.L. (1974) Spontaneous and testosterone-induced motility of isolated guinea-pig cauda epididymis. Experientia 30, 1063-1065.

Dyson, A.L.M.B. \& Orgebin-Crist, M.C. (1973) Effect of hypophysectomy, castration and androgen replacement upon the fertilizing ability of rat epididymal spermatozoa. Endocrinology 93, 391-402.

EI-Badawi, A. \& Schenk, E.C. (1967) The distribution of cholinergic and adrenergic nerves in the mammalian epididymis: a comparative histochemical study. Am. J. Anat. 121, 1-14.

Foldsey, R.G. \& Bedford, J.M. (1982) Biology of the scrotum. I. Temperature and androgen as determinants of the sperm storage capacity of the rat cauda epididymidis. Biol. Reprod. 26, 673-682.

Hib. J. (1976) Effects of autonomic drugs on epididymal contractions. Fert. Steril. 27, 951-956.

Hib, J. \& Ponzio. R.O. (1977) Effect of efferent duct ligation, gonadectomy and testosterone replacement on epididymal contractility in the rat. J. Reprod. Fert. 50, 327-329.

Hodson, N. (1970) The nerves of the testis, epididymis and scrotum. In The Testis, Vol. I, pp. 47-99. Eds A. D. Johnson, W. R. Gomes \& N. L. VanDemark. Academic Press, New York.

Jones, R. \& Glover, T.D. (1973) The effects of castration on the composition of rabbit epididymal plasma. $J$. Reprod. Fert. 34, 405-414.

Lubicz-Nawrocki, C.M. (1974) Effect of castration on the number of spermatozoa in the cauda epididymidis of hamsters. J. Reprod. Fert. 39, 97-100.

Martins, T. \& Valle, J.R. (1939) Endocrine control of motility of male accessory genital organs. Endocrinology 25, 80-90.

Meistrich, M.L., Hughes, T.J. \& Bruce, W.R. (1975) Alteration of epididymal sperm transport and maturation in mice by oestrogen and testosterone. Nature, Lond. 258, 145-147.

Moore, H.D.M. \& Bedford, J.M. (1979) The differential absorptive capacity of epithelial cells of the rat epididymis before and after castration. Anat. Rec. 193, 313-328.

Norberg, K.S., Risley, P.L. \& Ungerstedt, U. (1967) Adrenergic innervation of the male reproductive ducts in some mammals. II: Effects of vasectomy and castration. Experientia 23, 392-394.

Orgebin-Crist, M.C., Danzo, B.J. \& Davies, J. (1975) Endocrine control of the development and maintenance of sperm fertilizing ability in the epididymis. In Handbook of Physiology, Section 7: Endocrinology, Vol. 5: Male Reproductive System, pp. 319-338. Eds D. W. Hamilton \& R. O. Greep. American Physiological Soc., Washington, D.C.

Pholpramool, C. \& Sornpaisarn, L. (1980) Fertility and electrolyte composition of the rat cauda epididymal plasma and spermatozoa before and after castration. Contraception 22, 673-681.

Pholpramool, C. \& Triphrom, N. (1984) Effects of cholinergic and adrenergic drugs on intraluminal pressures and contractility of the rat testis and epididymis in vivo. J. Reprod. Fert. 71, 181-188.

Pholpramool, C., White, R.W. \& Setchell, B.P. (1982) Influence of androgens on inositol secretion and sperm transport in the epididymis of rats. J. Reprod. Fert. 66, 547-553.

Pholpramool, C., Triphrom, N. \& Din-Udom, A. (1984) Intraluminal pressures in the seminiferous tubules and in different regions of the epididymis in the rat. J. Reprod. Fert. 71, 173-179.

Prasad, M.R.N., Rajalakshmi, M., Gupta, G. \& Karkun, T. (1973) Control of epididymal function. J. Reprod. Fert., Suppl. 18, 215-222.

Risley, P.L. (1959) Hormone effects on the in vivo contractile behaviour of the ductus epididymis of the rat. Anat. Rec. 133, 329-330.

Risley, P.L. (1961) Effects of castration and testosterone on cholinesterase distributions in the rat epididymis and vas deferens. Anat. Rec. 139, 268.

Risley, P.L. \& Skrepetos, C.N. (1964) Histochemical distribution of cholinesterases in the testis, epididymis and vas deferens of the rat. Anat. Rec. 148, 231-248.

Wong, P.Y.D., Au, C.L. \& Ngai, H.K. (1978) Electrolyte and water transport in rat epididymis; its possible role in sperm maturation. Int. J. Androl., Suppl. 2, 608-627. 